\title{
The Eyjafjallajökull eruption in April 2010 - detection of volcanic plume using in-situ measurements, ozone sondes and lidar-ceilometer profiles
}

\author{
H. Flentje, H. Claude, T. Elste, S. Gilge, U. Köhler, C. Plass-Dülmer, W. Steinbrecht, W. Thomas, A. Werner, and \\ W. Fricke \\ Deutscher Wetterdienst, Meteorologisches Observatorium Hohenpeissenberg, Albin-Schwaiger-Weg 10, \\ 82383 Hohenpeissenberg, Germany
}

Received: 21 May 2010 - Published in Atmos. Chem. Phys. Discuss.: 18 June 2010

Revised: 13 October 2010 - Accepted: 14 October 2010 - Published: 26 October 2010

\begin{abstract}
Volcanic emissions from the Eyjafjallajökull volcano eruption on the Southern fringe of Iceland in April 2010 were detected at the Global Atmosphere Watch (GAW) station Zugspitze/Hohenpeissenberg (Germany) by means of in-situ measurements, ozone sondes and ceilometers. Information from the German Meteorological Service (DWD) ceilometer network (Flentje et al., 2010) aided identifying the air mass origin. We discuss ground level in-situ measurements of sulphur dioxide $\left(\mathrm{SO}_{2}\right)$, sulphuric acid $\left(\mathrm{H}_{2} \mathrm{SO}_{4}\right)$ and particulate matter as well as ozone sonde profiles and column measurements of $\mathrm{SO}_{2}$ by a Brewer spectrometer. At Hohenpeissenberg, a number of reactive gases, e.g. carbon monoxide and nitrogen oxides, and particle properties, e.g. size distribution and ionic composition, were additionally measured during this period. Our results describe the arrival of the volcanic plume at Zugspitze and Hohenpeissenberg during 16 and 17 April 2010 and its residence in the planetary boundary layer (PBL) for several days thereafter. The ash plume was first seen in the ceilometer backscatter profiles at Hohenpeissenberg in about 6-7 km altitude. After entrainment into the PBL at noon of 17 April, largely enhanced values of sulphur dioxide, sulphuric acid and super-micron-particle number concentration were recorded at Zugspitze/Hohenpeissenberg till 21 April.
\end{abstract}

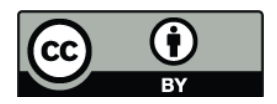

Correspondence to: $\mathrm{W}$. Thomas (werner.thomas@dwd.de)

\section{Introduction}

After months of enhanced seismic activity and crustal deformation close to the volcano summit, the Eyjafjallajökull volcano located in the south of Iceland $\left(63^{\circ} 38^{\prime} 0^{\prime \prime} \mathrm{N}\right.$, $19^{\circ} 36^{\prime} 0^{\prime \prime} \mathrm{W}$, summit $1660 \mathrm{~m}$ ) erupted on 20 March 2010; it was the first major outbreak after a relatively silent period of nearly 190 years. Fire fountains, lava jets and eruptions where visually observed but volcanic emissions remained in the troposphere. A major outbreak of the central crater under the covering ice cap followed on 14 April 2010 (Institute of Earth Sciences, 2010). The eruption became phreatomagmatic when water from the melting ice cap of the summit and surrounding glaciers met the lava. Large volcanic ash plumes rose up to the tropopause level $(\sim 10 \mathrm{~km})$ for days and were observed by satellite instruments.

A high pressure system in the South of Iceland on 14/15 April and later Western Scandinavia favored with northwesterly winds the transport of large amounts of erupted material, mostly volcanic ash, water vapour, and sulphur dioxide $\left(\mathrm{SO}_{2}\right)$, across the North-Eastern Atlantic towards the British Islands, Scandinavia and later on to Central Europe. Volcanic ash particles may heavily affect aircraft (Miller and Casadevall, 2000) because, like in this case, they can be highly abrasive and can have melting temperatures below that within aircraft engines. Therefore the detection and tracking of ash plumes e.g. by satellites and airborne or groundbased remote sensing for aviation hazard mitigation is indispensable for Volcanic Ash Advisory Centers (VAAC) (Carn et al., 2008; Prata, 2008). The London VAAC, being responsible for the Northern European sector including Iceland, issued warnings

Published by Copernicus Publications on behalf of the European Geosciences Union. 
about the presence of the ash plume over large parts of Europe, based on aviation regulations in force by that time. Consequently, the majority of European airports was closed from 15-21 April 2010. Since then the Eyjafjallajökull exhibited variable activity and series of eruptions caused further volcanic emissions (see e.g., Institute of Earth Sciences, 2010) that reached the British Islands, the Iberian peninsula, the Azores, and Italy interrupting air traffic again, e.g. from 5-8 May 2010 and from 10-12 May 2010. The spatial coverage of volcanic emissions over Europe and the Atlantic ocean was monitored e.g. by satellites but also trajectory calculations and model simulations were used to either detect or forecast the presence of ash clouds and sulphur dioxide in the atmosphere. From the ground, the ash cloud was observed by EARLINET lidars and suitable lidar-ceilometers (e.g., Ansmann et al., 2010; Flentje et al., 2010). Starting on 19 April the Falcon 20 research aircraft of the German Aerospace Center (DLR) performed a series of flights analysing the ash cloud in-situ over Central Europe up to Iceland (Schumann et al., 2010).

The first eruptive period of the Eyjafjallajökull between 14 and 19 April caused volcanic ash plumes reaching Northern Germany between 2 and $7 \mathrm{~km}$ altitude during the night from 15 April to 16 April; the ash subsided and swayed southward on 16 and 17 April (Flentje et al., 2010). In southern Germany it was entrained into the planetary boundary layer after noon of 17 April. The air mass was deflected towards west and east at the Alps and resided over central Europe for several days thereafter. In our study we describe the temporal evolution of this event, using collocated in-situ measurements of trace gases and aerosol particles at Hohenpeissenberg and Zugspitze (Germany), ozone sondes (Hohenpeissenberg) and observations from a newly established network of aerosol profiling ceilometers in Germany (Flentje et al., 2010).

\section{Measurements of volcanic emissions}

\subsection{DWD lidar-ceilometer network observations}

The spatial and temporal evolution of the volcanic emissions over Germany was tracked by the ceilometer network of the German Meteorological Service (DWD) as described in detail by Flentje et al. (2010). Ceilometers, intentionally designed for cloud base height monitoring, during the recent years evolved to affordable low-maintenance low-power elastic backscatter lidars like the Jenoptik CHM15K (http: //www.jenoptik.com) instruments operated by the DWD. The CHM15k use a diode-pumped Nd:YAG solid state laser which allows the detection of optically thin aerosol layers from about $600 \mathrm{~m}$ above ground up to $15 \mathrm{~km}$ with a vertical resolution of $15 \mathrm{~m}$. During the Eyjafjallajökull eruption phase (spring 2010) about 36 ceilometers were operational in Germany.
CHM15K lidar-ceilometers provide vertical profiles of total (molecular + particulate) elastic backscatter. In general they are not sensitive enough to allow absolute calibration by Rayleigh scattering at $1064 \mathrm{~nm}$, but collocated aerosol optical depth measurements may allow calibration even so (Flentje et al., 2010; Heese et al., 2010). Operation in the near-IR implies large contrast of particle layers versus the molecular background but on the other hand, the scattering efficiency drops down sharply for smaller particles with radii well below $1 \mu \mathrm{m}$. Details about solving the lidar equation for the backscatter coefficient profile (e.g., Fernald, 1984; Klett, 1981) and the necessary assumptions can be found in the comprehensive lidar literature (e.g., Böckman et al., 2004).

\subsection{In-situ measurements}

In-situ measurements of volcanic emissions are typically confined to particle measurements and sulphur dioxide concentrations in ambient air. Furthermore, the chemical composition of aerosols and rainwater samples can be analyzed retrospectively (Zerefos et al., 2006). Such measurements are continuously performed by DWD at the Global Atmosphere Watch (GAW) station Zugspitze/Hohenpeissenberg, including the Environmental Research Station (UFS) "Schneefernerhaus" (http://www.schneefernerhaus.de/e-ufs. $\mathrm{htm}, \quad 47.4^{\circ} \mathrm{N}, \quad 11.0^{\circ} \mathrm{E} 2650 \mathrm{~m}$ a.s.1., $300 \mathrm{~m}$ below the Zugspitze summit) in the Northern alpine area, and at the Hohenpeissenberg Meteorological Observatory HPB (http: //www.dwd.de/gaw, $47.8^{\circ} \mathrm{N}, 11.0^{\circ} \mathrm{E} 985 \mathrm{~m}$ a.s.l.) located on a northern alpine foothill $300 \mathrm{~m}$ above the surrounding countryside (Mannschreck et al., 2004).

Sulphur dioxide is measured with UV pulsed fluorescence analyzers by Thermo Instruments Inc., (model TE43i TLE at UFS and TE43 CTL at HPB), both with detection limits of about $50 \mathrm{ppt}$ (parts per trillion $=$ picomole $/ \mathrm{mole}$ ). Sulphur dioxide in-situ measurements are performed since 1995 at the Hohenpeissenberg Observatory and since 2000 also at the "Schneefernerhaus". Furthermore, measurements (only at $\mathrm{HPB})$ of sulfuric acid $\left(\mathrm{H}_{2} \mathrm{SO}_{4}\right)$ are performed by a Chemical Ion Mass Spectrometer (CIMS) instrument involving continuous sampling of ambient air, followed by chemical ionisation with $\mathrm{NO}_{3}^{-}$ions, cluster dissociation, and mass selective detection (Berresheim et al., 2003). CIMS observations of $\mathrm{H}_{2} \mathrm{SO}_{4}$ started in the late nineties and are operated routinely for more than 10 years now.

Particle number concentration is measured at the UFS since 2000 by a Nolan-Pollak condensation particle counter (CPC) and since 2006 by a Butanol-based CPC (model TSI 3025a). At HPB, number concentrations of particles larger than $3 \mathrm{~nm}$ are continuously available since 1995 (TSI CPC 3025a, 3762, now also 3772, 3776), $\mathrm{PM}_{10}$-mass concentration is measured by TEOM (model 1400a, Rupprecht and Patashnick), the scattering coefficient by a three wavelengths nephelometer (center wavelengths $450 \mathrm{~nm}, 550 \mathrm{~nm}, 700 \mathrm{~nm}$, model TSI 3563). The particle size distribution is recorded 
Table 1. Measured aerosol quantities and trace species at HPB and UFS between 16 and 23 April (norm. = normal, high, enh. =enhanced, dist. $=$ disturbed, undist. $=$ undisturbed $)$

\begin{tabular}{lllllllll}
\hline Date & $\begin{array}{l}\text { Ceilo- } \\
\text { meters }\end{array}$ & $\begin{array}{l}\mathrm{SO}_{2} \mathrm{HPB} \\
\text { in-situ }\end{array}$ & $\begin{array}{l}\mathrm{SO}_{2} \mathrm{UFS} \\
\text { in-situ }\end{array}$ & $\begin{array}{l}\mathrm{SO}_{2} \text { col. } \\
\text { Brewer }\end{array}$ & $\begin{array}{l}\mathrm{H}_{2} \mathrm{SO}_{4} \\
\text { in-situ }\end{array}$ & $\begin{array}{l}\text { particle } \\
\text { number } \\
\text { conc HPB }\end{array}$ & $\begin{array}{l}\text { particle } \\
\text { number } \\
\text { conc UFS }\end{array}$ & $\begin{array}{l}\text { ozone } \\
\text { sonde } \\
\text { profile }\end{array}$ \\
\hline $16 \mathrm{Apr}$ & & enh. & norm. & norm. & norm. & enh. & norm. & undist. \\
$17 \mathrm{Apr}$ & ash plume & high & high & high & high & enh. & high & $\begin{array}{l}\text { dist. } \\
\text { enh. }\end{array}$ \\
$18 \mathrm{Apr}$ & ash layers & high & enh. & norm. & enh. & undist. \\
$19 \mathrm{Apr}$ & ash layers & high & high & norm. & high & high & high & undist. \\
$20 \mathrm{Apr}$ & ash layers & high & enh. & high & high & high & norm. & undist. \\
$21 \mathrm{Apr}$ & ash layers & high & norm. & norm. & high & high & enh. & dist. \\
$22 \mathrm{Apr}$ & ash layers & high & norm. & norm. & enh. & enh. & enh. & dist. \\
$23 \mathrm{Apr}$ & ash layers & norm. & norm. & norm. & enh & enh. & norm. & dist. \\
\hline
\end{tabular}

at HPB by an optical particle counter (GRIMM-OPC, $d=$ $0.3 \mu \mathrm{m}-30 \mu \mathrm{m})$ and aerodynamically by a Scanning Mobility Particle Sizer (SMPS, $d=10 \mathrm{~nm}-900 \mathrm{~nm}$ ) which was recently (2009) equipped with a separate thermodenuder sampling channel for quantification of the non-volatile aerosol fraction.

\subsection{Ozone sondes and sulphur dioxide column measurements}

The Hohenpeissenberg observatory acts as the Regional Ozone Center of the Regional Association VI (RA) of the World Meteorological Organization (WMO). As part of this activity a Brewer spectrometer is operated since 1983. These types of instruments are partly sensitive to sulphur dioxide and can be used to estimate the total atmospheric $\mathrm{SO}_{2}$ content. The Brewer instruments are however designed to measure primarily the atmospheric ozone content while the retrieval of sulphur dioxide is a side effect of these measurements being necessary for correct ozone measurements. A larger uncertainty of sulphur dioxide amounts retrieved from Brewer data is therefore expected, as it is discussed in detail by Fioletov et al. (1998).

The ozone center at the Hohenpeissenberg observatory launches ozone sondes (Brewer Mast) regularly since 1967, e.g. supporting international programmes monitoring the evolution of the atmospheric ozone content. Brewer Mast ozone sondes are being coupled with Vaisala RS92 radiosondes and are normally launched 2-3 times per week. The sonde measures ozone partial pressure, temperature, pressure, humidity, windspeed and -direction every second. Geographical coordinates and geometrical altitude are provided by a GPS module. During flight the data stream is transmitted in real-time to the ground station.

\section{Results and discussion}

A synopsis of different measurements and results on the days between 16 and 23 April, given in Table 1, shows that the main ash event at the Zugspitze and Hohenpeissenberg sites started on 17 April and ceased on 21 and 23 April, respectively.

\subsection{Ash plume dispersion over Germany}

The eruption of the Icelandic Eyjafjallajökull volcano from 14 April 2010 onward massively injected particles into the troposphere up to about $10 \mathrm{~km}$ altitude (Institute of Earth Sciences, 2010, Institute of Earth Sciences, University of Iceland). After their arrival over northern Germany in the evening of 16 April, the DWD ceilometer network tracked the deformation and dispersion of the ash plume (Flentje et al., 2010). The initially fast moving multilayer ash front crossed northern Germany within about 8 $12 \mathrm{~h}$ on early 16 April and then swayed southward over Germany. Thereby the ash front arrived over Germany in about 6-7 km height and within several hours concentrated between $2-4 \mathrm{~km}$ altitude only, forming a dense, roughly one $\mathrm{km}$ thick layer. Subsidence $(1-2 \mathrm{~km} /$ day according to ECMWF analyses) and the layer's slope (CALIPSO on 17 April, http://www-calipso.larc.nasa.gov/products/lidar/ browse_images) comparably contributed to an apparent descent of the layer at the station locations. In Fig. 1 this appears as a down tilting red-coloured layer. Note that the seemly intermittence of the layer is due to low clouds which prevented the observation of the ash-layer above.

On 17 April the primary ash layer had crossed most of Germany and was only observed over the cloud-free parts of southern Germany where it was entrained into the convective PBL from noon onwards (Fig. 2). Referring to the $3 \mathrm{~km}$ altitude level, the ash layer arrived $6 \mathrm{~h}$ earlier at Hohenpeissenberg ( 17 April, $\approx 06: 00 \mathrm{UT}$ ) than at the Zugspitze (12:00 UT). The main event from 16 April till 20 April as seen by the HPB ceilometer is depicted in Fig. 1. At 


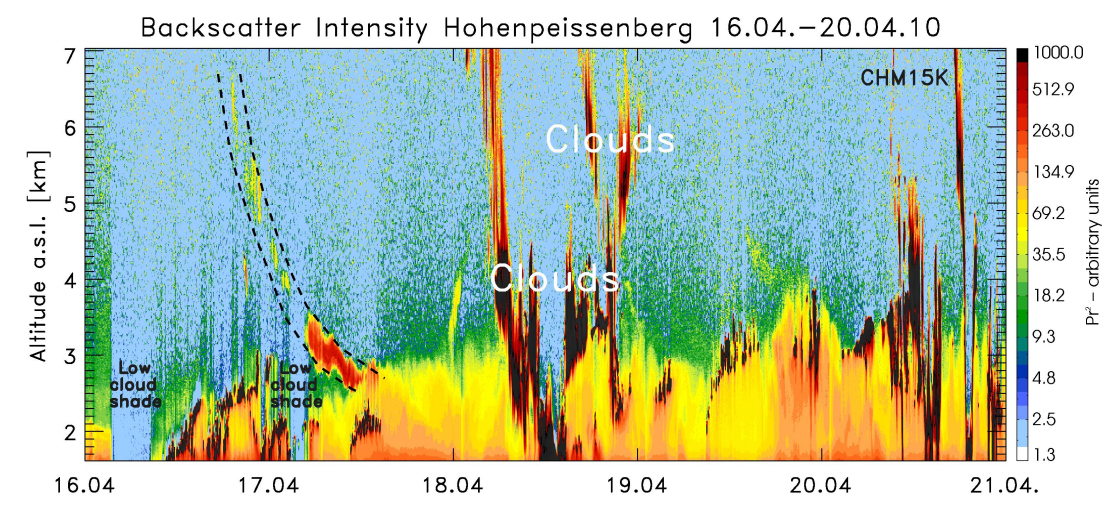

Fig. 1. Time series of ceilometer backscatter profiles at Hohenpeissenberg from 16 to 20 April 2010. Low clouds are often hampering the observation of higher layers above while the arrival and entrainment of the main ash plume into the PBL (indicated by dashed lines) could be observed during a mostly cloud-free period. Thin ash layers are evident also on 18 April, $\approx 00: 00$ UT (3-4 km) and on 19 April all the day (most pronounced $\approx 00: 00 \mathrm{UT}$ in $3-4 \mathrm{~km}$ and in the afternoon around $4 \mathrm{~km}$.

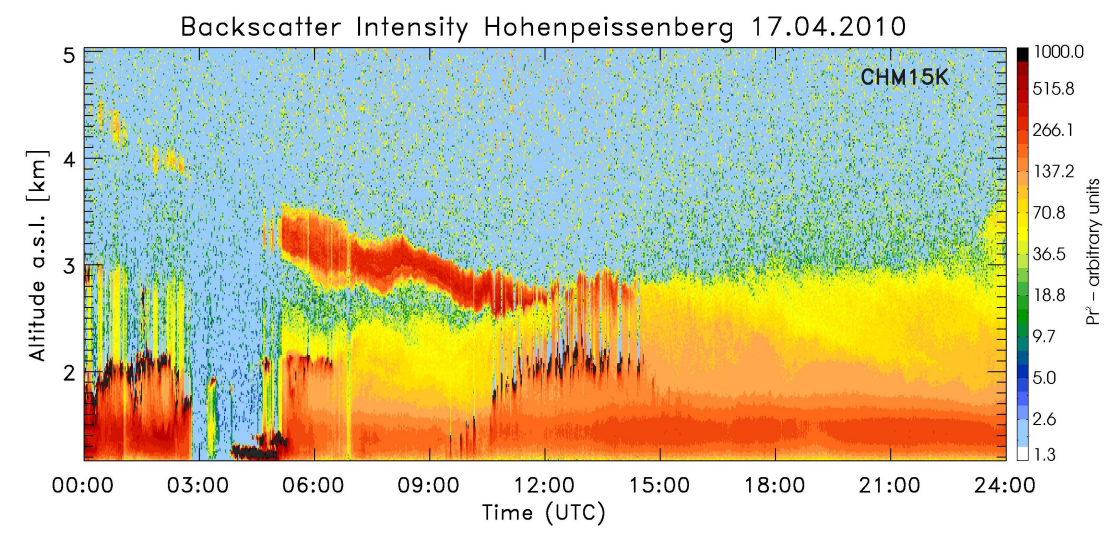

Fig. 2. Range corected backscatter intensity section obtained from the Hohenpeissenberg ceilometer on 17 April. The descent of the ash plume during morning hours in about $4-5 \mathrm{~km}$ is evident, although low-level clouds partly shadowed the backscatter signal from above. The entrainment of the ash plume into the planetary boundary layer starts around local noon.

Hohenpeissenberg the peak extinction coefficients and the mass concentrations on 17 April 17 were roughly estimated to be $5( \pm 2) 10^{-4} \mathrm{~m}^{-1}$ and $600( \pm 400) \mu \mathrm{g} / \mathrm{m}^{3}$, respectively, using co-located aerosol optical depth and nephelometer (scattering coefficient) measurements (see details in Flentje et al., 2010) for constraining the backscatter profile.

\subsection{Ground-based in-situ observations}

The global atmospheric sulphur dioxide budget is controlled by natural emissions from volcanoes, the oceans (formation of $\mathrm{SO}_{2}$ from dimethylsulphide, $\mathrm{H}_{2} \mathrm{~S}$ ) and anthropogenic emissions (Graf et al., 1997), and the removal of $\mathrm{SO}_{2}$ by wet deposition and reaction with the $\mathrm{OH}$ radical mainly in the troposphere. Due to its tropospheric life time of typically several days it is an excellent tracer of long-range transport of volcanic emissions but also for anthropogenic emissions. In volcanic ash plumes, sulphur dioxide is substantially enhanced and subsequently sulphuric acid may be formed dur- ing day (photochemistry), thus giving rise to secondary particle formation. Accordingly, number concentrations in ash plums are generally enhanced due to primary ash particles ( $\mu \mathrm{m}$ size range) and occasionally newly generated smaller particles.

Simultaneously with the arrival of the ash plume, the surface concentrations of $\mathrm{SO}_{2}$ and large particles rose from background concentrations to high levels both at the "Schneefernerhaus" and later at HPB during the morning of 17 April. The strong increase was more pronounced at the UFS where the largest $\mathrm{SO}_{2}$ mixing ratio of about $3.5 \mathrm{ppb}$ (parts per billion) in April since the beginning of the measurements was recorded (Fig. 3). The higher $\mathrm{SO}_{2}$ values at the UFS support the finding (from the ceilometer measurements) that the volcanic plume subsided from higher atmospheric levels into the planetary boundary layer (PBL). Available ECMWF analyses indicated subsidence of about $1000-2000 \mathrm{~m} /$ day in $3-5 \mathrm{~km}$ altitude, satellite data from the Cloud-Aerosol Lidar with Orthogonal Polarization 


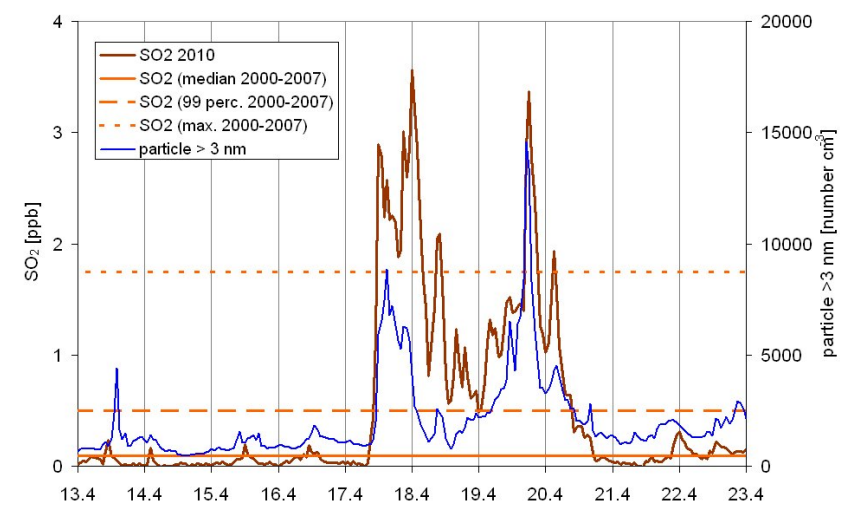

Fig. 3. $\mathrm{SO}_{2}$ mixing ratios and particle number concentrations $(>3 \mathrm{~nm})$ measured by DWD at the GAW Global Station Zugspitze/Hohenpeissenberg, platform Zugspitze/UFS at $2650 \mathrm{~m}$ elevation. The particle number concentrations are highly correlated with $\mathrm{SO}_{2}$. The continuous and dashed red lines indicate the median, the 99-percentile and the maximum observed (year 2000-2007) values of the $\mathrm{SO}_{2}$ mixing ratios at "Schneefernerhaus".

(CALIOP) instrument onboard the Cloud-Aerosol Lidar and Infrared Pathfinder Satellite Observations (CALIPSO) spacecraft indicate that the layer was strongly tilted (e.g. on 16 April over Belgium). The layer observed at Zugspitze resembled the one at Hohenpeissenberg and at other southern German ceilometer stations in detail, strongly indicating that the same layer reached both observation sites. This is also supported by the relatively low horizontal distance and the temporal coincidence between the measurements.

After reaching their first maximum during the night 17/18 April, $\mathrm{SO}_{2}$ decreased on 18 April but exhibited a second maximum in the afternoon of 19 April. The concentrations fell back to background levels during 21 April. The particle number concentration of particles larger than $3 \mathrm{~nm}$ are highly correlated with $\mathrm{SO}_{2}$ measurements (as well as corresponding PM10 values measured by the Federal Environmental Agency UBA, L. Ries personnel communication, 2010, not shown here). Aerosol parameters and $\mathrm{SO}_{2}$ show both a coincident maximum and similar temporal variation.

At HPB, $40 \mathrm{~km}$ north of the UFS and situated in the PBL, also clear signs of volcanic impact were observed, though partially masked by enhanced anthropogenic background. Sulphur dioxide mixing ratios rose from the afternoon of 17 April (14:30 CEST) to several consecutive peaks around $1.5 \mathrm{ppb}$ on 19-22 April in five distinct maxima (see Fig. 4). Highest values of about $2.3 \mathrm{ppb}$ were seen during morning hours on 21 April (Fig. 4), being higher than the 99 percentile for hourly measurements in April between 2000 and 2007. The daily pattern of anthropogenic tracers such as carbon monoxide $(\mathrm{CO})$, nitrogen oxides $\left(\mathrm{NO}, \mathrm{NO}_{\mathrm{y}}\right)$ and ozone $\left(\mathrm{O}_{3}\right)$ did not not show any unusual temporal changes, indicating that the enhanced $\mathrm{SO}_{2}$ at $\mathrm{HPB}$ is not due to anthropogenic emissions. Dust events on the other side (e.g. from the Saha-

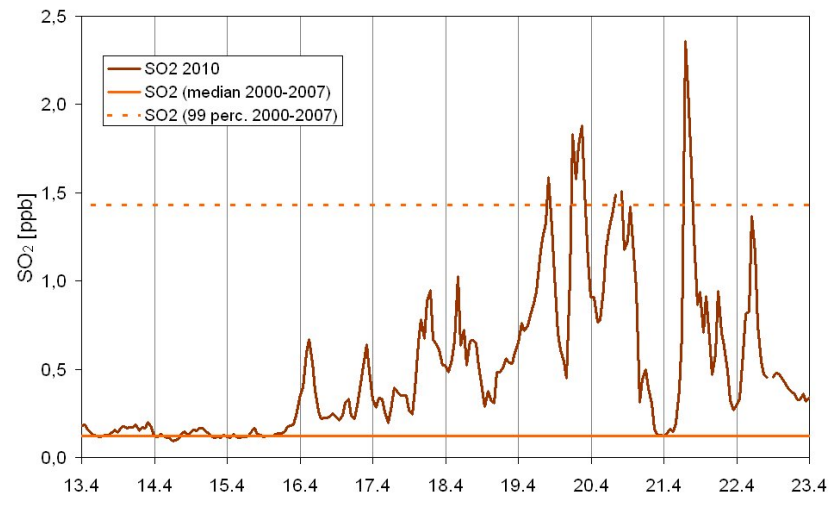

Fig. 4. $\mathrm{SO}_{2}$ mixing ratio measured at the GAW Global Station Zugspitze/Hohenpeissenberg, platform HPB at $980 \mathrm{~m}$ elevation. The continuous and dashed red lines indicate the median and the 99-percentile values of the $\mathrm{SO}_{2}$ mixing ratios at Hohenpeissenberg.

ran) would not be associated with enhanced $\mathrm{SO}_{2}$ concentrations. We therefore interpret our measurements in the sense that we indeed monitored the volcanic ash plume.

Parallel observations of the CIMS instrument at HPB allowed measurements of the ambient concentration of sulfuric acid. Enhanced levels of $\mathrm{SO}_{2}$ are expected to further translate into higher values of $\mathrm{H}_{2} \mathrm{SO}_{4}$. Oxidation of sulphur dioxide by the $\mathrm{OH}$ radical is the main atmospheric sink of $\mathrm{SO}_{2}$ and this process is more efficient for higher solar radiation. Associated with high $\mathrm{SO}_{2}$ and intensive photochemistry, peak sulphuric acid concentrations on 19 April were above the hereto observed maxima in April (Fig. 5).

The arrival of the plume is also evident from the sharply increasing number concentration of particles larger than $1 \mu \mathrm{m}$, measured by an optical particle counter at HPB on 17 April, in coincidence with the ash entrainment into the PBL as indicated by the ceilometer backscatter profiles. Supermicron particle concentrations were enhanced from 17-23 April as shown in Fig. 6. No significant enhancement was observed for particles larger than $7.5 \mu \mathrm{m}$ upon arrival of the ash particles at ground level. This is in line with expectations of sedimentation velocities of few-micron-sized particles which are of the order of several $\mathrm{m} / \mathrm{h}$ in the lower and mid troposphere. Larger particles of $20 \mu \mathrm{m}$ diameter would have settled however by roughly $5-6 \mathrm{~km}$ within the two days after the eruption. The sudden increase of super-micron particle concentrations goes along with the enhancement of ambient $\mathrm{SO}_{2}$. The abundance of particles smaller than $0.5 \mu \mathrm{m}$ was not affected, corresponding to typical size distributions reported for tropospheric volcanic ash e.g. by Rose and Durant (2009). Nonetheless, the virtual absence of the small particle fraction within the ash cloud remains a bit odd. The small particles in volcanic ash plumes are typically composed largely of sulphuric acid. In principle, they could either condense onto the hydrophobic large ash particles, i.e. the large particles would act as condensational sink for the smaller ones (However, yet 


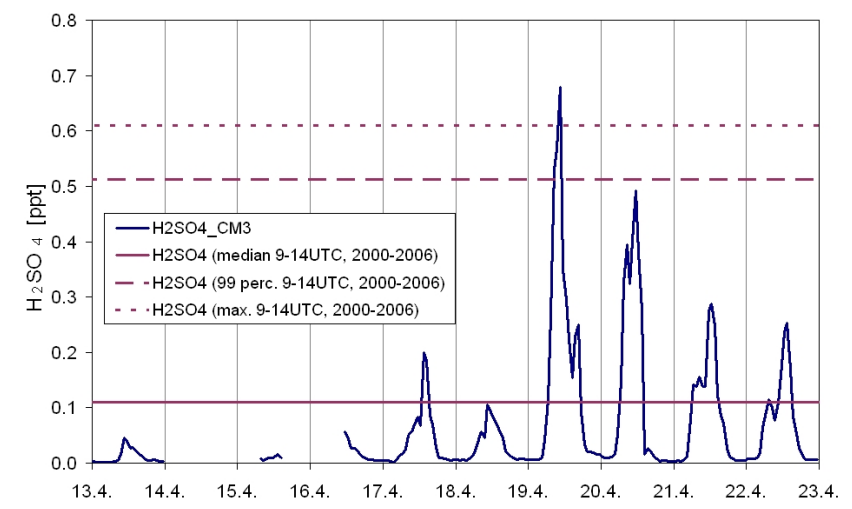

Fig. 5. Sulfuric acid $\left(\mathrm{H}_{2} \mathrm{SO}_{4}\right)$ measurements at the GAW Global Station Zugspitze/Hohenpeissenberg, platform HPB at $980 \mathrm{~m}$ elevation as derived from a Chemical Ion Mass Spectrometer (CIMS). The continuous and dashed purple lines indicate the median, the 99percentile and the maximum observed (year 2000-2006) values of the $\mathrm{H}_{2} \mathrm{SO}_{4}$ mixing ratios at Hohenpeissenberg.

no in-situ observations confirm the existence of hydrophilic coatings on the large particles). Or, as small sulphuric acid particles are more efficiently captured by cloud droplets they could subsequently be washed out of the atmosphere more efficiently. In any case, if there has been generation and subsequent removal of accumulation mode particles, the latter must have been much more rapid than gravitational sedimentation of ash particles alone which is typically of the order of some ten meters per day.

Particle mass concentrations increased from $20 \mu \mathrm{g} / \mathrm{m}^{3}$ to $40 \mu \mathrm{g} / \mathrm{m}^{3}$ (in peak $50 \mu \mathrm{g} / \mathrm{m}^{3}$ ) on 17 April and remained elevated till 23 April. Local precipitation on 18 April and 20 April repeatedly washed out particles but the widely distributed ash caused again locally increasing particle concentrations shortly after scavenging.

Filter probes, taken at HPB for chemical analysis of rain water probes and water-soluble aerosols, support the presence of volcanic emissions as well. Enhanced concentrations and deposition of heavy metals ions (iron, manganese) were found in weekly rain water probes, although not being extraordinary high if compared to other samples during the last 1.5 years. Daily rain water probes analyzed by ion chromatography showed higher (but not unusually high) amounts of sulphate, fluorine and calcium ions indicating altogether the presence of volcanic emissions.

\subsection{Ozone sondes and total column measurements}

Ozone sondes were launched daily between 14 and 25 April 2010 (excluding 15 April). The launch on April 19th supported a flight campaign carried out by the Falcon research aircraft of the German Aerospace Center (DLR) in the afternoon around 14:15 UTC. Little is known about the impact of volcanic ash and/or volcanic sulphur dioxide (and precursor

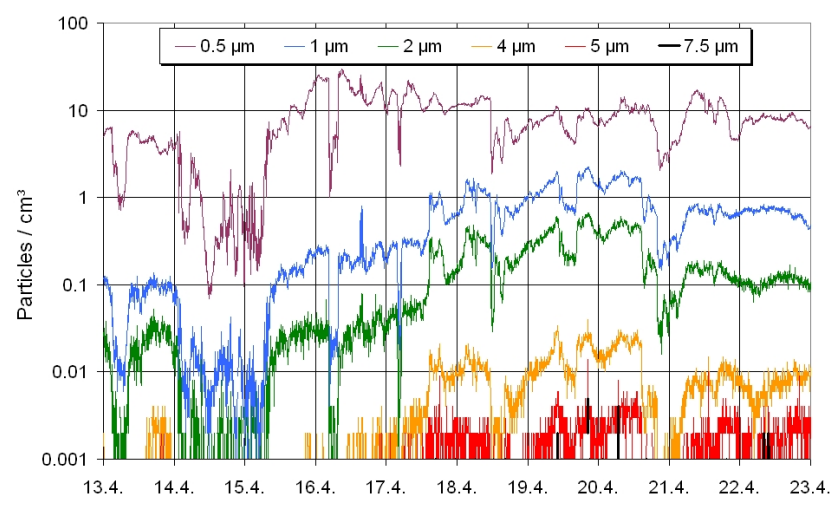

Fig. 6. Size-resolved particle number concentration at the GAW Global Station Zugspitze/Hohenpeissenberg, platform Hohenpeissenberg at $980 \mathrm{~m}$ elevation as derived from an optical particle counter (GRIMM-OPC).

components) on ozone sonde measurements (Schenkel and Broder, 1982).

The ozone profile from the sonde launched on 16 April did not show any unusual concentration levels in the troposphere and lower stratosphere. The ozone profile from 17 April showed however a severely disturbed ozone profile in the lower troposphere between $2.5 \mathrm{~km}$ and $7 \mathrm{~km}$ a.s.l. (Fig. 7). We therefore conclude that the volcanic plume arrived between 16 and 17 April at Hohenpeissenberg. Layers with reduced ozone appeared also during the following days in the higher troposphere/tropopause region, but not as pronounced as on Saturday, 17 April. For comparison, the white and grey areas show the range of ozone values observed in April 2007 to 2009 .

In fact, such a distorted profile was never recorded before in the more than 40 years history of ozone sondes launched at Hohenpeissenberg. Also, the ozone sonde launched by the Koninklijk Nederlands Meteorologisch Instituut (KNMI) at DeBilt on 16 April (one day earlier) showed a similar pattern in the lower troposphere between $2 \mathrm{~km}$ and $5 \mathrm{~km}$ (V. Huijnen, personal communication, 2010). At that time the ash plume arrived from north-westerly direction at the Netherlands and Northern Germany. Part of the registered low ozone values maybe caused by $\mathrm{SO}_{2}$ interfering with the wetchemical measurement: $1 \mathrm{ppb} \mathrm{SO}_{2}$ is registered as $-1 \mathrm{ppb}$ $\mathrm{O}_{3}$ (Schenkel and Broder, 1982). Effects of volcanic ash on the measurements can also not be excluded. It is however plausible that substantial ozone amounts were destroyed in the Eyjafjallajökull plume. Enhanced ozone depletion was also observed by aircraft measurements in the plume on 3 May 2010 (Schumann et al., 2010).

The $\mathrm{SO}_{2}$ observations at the UFS coincide further with the $\mathrm{SO}_{2}$ columnar measurements of the Brewer spectrometer at Hohenpeissenberg (Fig. 8). The Brewer spectrometer detected a columnar content of 0.7 DU (Dobson units) on 17 April (daily mean). This corresponds to a layer of about $3 \mathrm{~km}$ thickness at a concentration of $3 \mathrm{ppb} \mathrm{SO}$, or a $1 \mathrm{~km}$ 


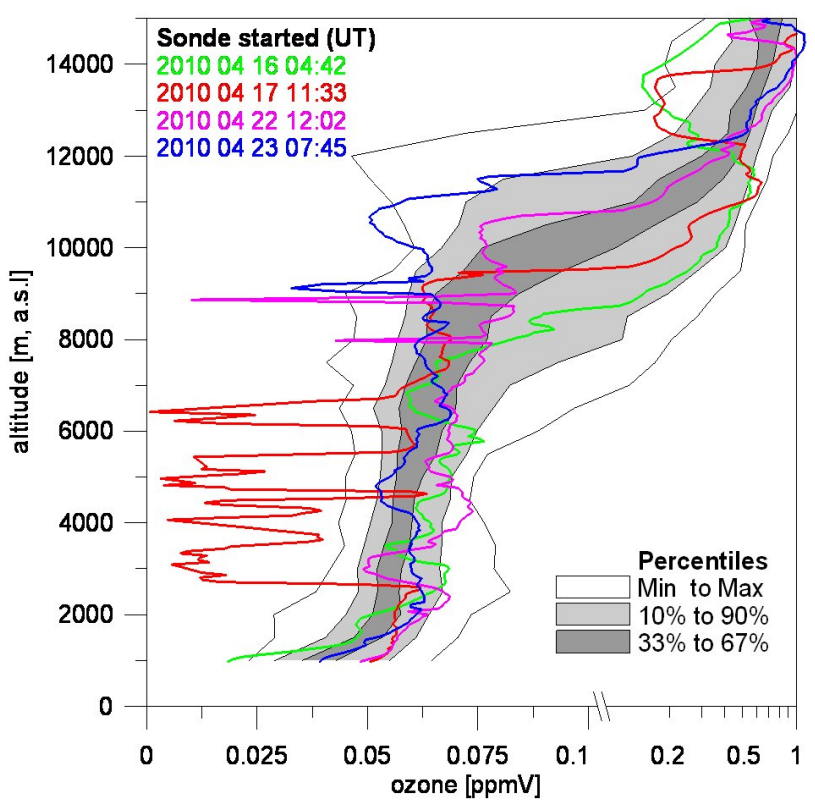

Fig. 7. Ozone profiles derived from ozone sondes launched at Hohenpeissenberg between 16 and 23 April. On 17 April the ozone content between $2.5 \mathrm{~km}$ and $7 \mathrm{~km}$ is largely reduced within several distinct layers (red curve). Grey-shaded areas show the 10-90 and 33-67 percentiles of all April measurements of years 2007 to 2009 , respectively. An undisturbed ozone profile was observed on 14 April (green) while the ozone profiles of 22 April (magenta) and 23 April (blue) showed layers with sharply dropped ozone concentrations between $8 \mathrm{~km}$ and $9 \mathrm{~km}$.

layer at $10 \mathrm{ppb} \mathrm{SO}_{2}$. The latter concentration/layer combination better corresponds to the thickness of the ash layer as derived from the Hohenpeissenberg ceilometer, while the former combination better supports the concentration measured at the USF. Differences between the thickness of the ash layer and the corresponding $\mathrm{SO}_{2}$ layer could be due to different sedimentation processes. The ash plume arrived later at the USF and it therefore appears plausible that the volcanic emissions have started to interfere and mix into the planetary boundary layer causing reduced concentrations. The "Schneefernerhaus" might have been additionally influenced by upslope winds with potentially lower $\mathrm{SO}_{2}$ mixing ratios. A second relative maximum of the $\mathrm{SO}_{2}$ column of about $0.4 \mathrm{DU}$ was observed on 20 April which corresponds to enhanced $\mathrm{SO}_{2}$ levels in ambient air at Hohenpeissenberg. The low total $\mathrm{SO}_{2}$ columns on 18 and 19 April are probably due to precipitation at Hohenpeissenberg during the evening hours on 18 April $(1.8 \mathrm{~mm})$.

\section{Conclusions}

Under clear sky conditions, optical remote sensing instruments from the ground can retrieve the vertical distributions of volcanic ash (ceilometers, aerosol lidars, MAXDOAS) or the total column in case of $\mathrm{SO}_{2}$ (Brewer, MAXDOAS). For

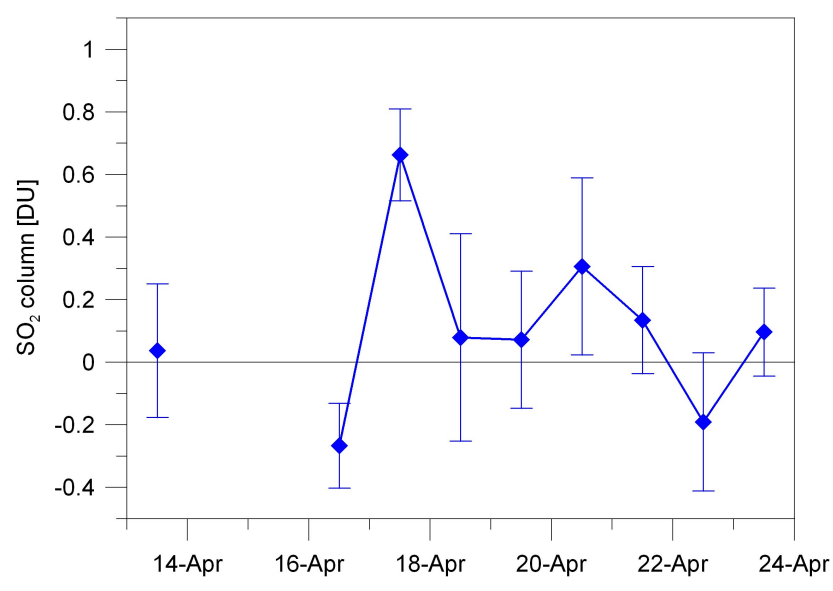

Fig. 8. $\mathrm{SO}_{2}$ column measurements (daily means) by the Hohenpeissenberg Brewer spectrometer. Maximum column densities of about 0.7 DU were measured on 17 April (corresponding to a $3 \mathrm{~km}$ layer with 3 ppb SO 2 ).

an unambiguous identification of volcanic ash plumes, however, in-situ measurements of such layers from high mountain stations, balloons and aircraft, where concentrations of the volcanic ash can be determined directly, are highly recommended. Airborne observations also allow measurements when low clouds hinder the use of optical remote sensing instruments from ground stations.

Our study shows that measurements collected at the GAW global station Zugspitze/Hohenpeissenberg and profile data from collocated ceilometers can be used together to describe the spatial and temporal evolution of the Eyjafjallajökull ash plume that passed Central Europe from 16 to 26 April 2010. Ceilometer data fitted well into in-situ measurements gathered at Hohenpeissenberg and the "Schneefernerhaus". Obtained backscatter profiles indicated the arrival of the ash layers over HPB together with simultaneously increasing $\mathrm{SO}_{2}$ and $\mathrm{H}_{2} \mathrm{SO}_{4}$ concentrations, as well as the increasing number concentration of larger particles $(d>1-7.5 \mu \mathrm{m})$, supported by the chemical composition of rain water. Measured $\mathrm{SO}_{2}$ concentrations at UFS and $\mathrm{H}_{2} \mathrm{SO}_{4}$ concentrations at $\mathrm{HPB}$ where well above the maximum levels ever observed in April at both the stations since measurements started in 2000 and 1998, respectively.

We conclude that combined observations of $\mathrm{SO}_{2}$ and particles backed by measurements of anthropogenic trace gases $\left(\mathrm{CO}, \mathrm{NO}, \mathrm{NO}_{2}\right)$ form unique tracers to detect volcanic ash layers in the atmosphere. Other sources of enhanced particle concentrations due to anthropogenic emissions and dust could be ruled out by missing coincident increases of $\mathrm{CO}$ and nitrogen oxides in case of anthropogenic plumes.

Acknowledgements. This work was partially supported by the European 7th Framework Programme MACC (Monitoring Atmospheric Composition and Climate). We thank our colleagues of Deutscher Wetterdienst at Offenbach and the meteorological obser- 
vatory Lindenberg for providing analysis data and support for the analysis of the ceilometer data. Special thanks to all our colleagues from the Hohenpeissenberg Meteorological observatory, especially M. Adelwart, M. Fricke and N. Kreitner, and the Zugspitze weather station making this study possible by their continuous technical and engineering support. We finally would like to thank the two reviewers for their helpful comments and recommendations.

Edited by: R. von Glasow

\section{References}

Ansmann, A., Tesche, M., Gross, S., Freudenthaler, V., Seifert, P., Hiebsch, A., Schmidt, J., Wandinger, U., Mattis, I., Müller, D., and Wiegner, M.: The 16 April 2010 major volcanic ash plume over central Europe: EARLINET lidar and AERONET photometer observations at Leipzig and Munich, Germany, Geophys. Res. Lett., 37, L13810, doi:10.1029/2010GL043809, 2010.

Berresheim, H., Plass-Dülmer, C., Elste, T., Mihalopoulos, N., and Rohrer, F.: $\mathrm{OH}$ in the coastal boundary layer of Crete during MINOS: Measurements and relationship with ozone photolysis, Atmos. Chem. Phys., 3, 639-649, doi:10.5194/acp-3-639-2003, 2003.

Böckman, C., Wandinger, U., Ansmann, A., et al.: Aerosol lidar intercomparison in the framework of the EARLINET project. 2. Aerosol Backscatter Algorithms, Appl. Opt., 43, 977-989, 2004.

Carn, S., Krueger, A., Krotkov, N., Yang, K., and Evans, K.: Tracking volcanic sulfur dioxide clouds for aviation hazard mitigation, Nat. Hazards, 51, 325-343, doi:10.1007/s11096-008-9228-4, 2008

Fernald, F.: Analysis of atmospheric lidar observations: some comments, Appl. Optics, 23, 652-653, 1984.

Fioletov, V., Griffioen, E., Kerr, J., Wardle, D., and Uchino, O.: Influence of volcanic sulfur dioxide on spectral UV irradiance as measured by Brewer spectrophotometers, Geophys. Res. Lett., 25, 1665-1668, 1998.

Flentje, H., Heese, B., Reichardt, J., and Thomas, W.: Aerosol profiling using the ceilometer network of the German Meteorological Service, Atmos. Meas. Tech. Discuss., 3, 3643-3673, doi:10.5194/amtd-3-3643-2010, 2010.

Graf, H.-F., Feichter, J., and Langmann, B.: Volcanic sulfur emissions: Estimates of source strength and its contribution to the global sulfate distribution, J. Geophys. Res., 102, 10727-10738, 1997.
Heese, B., Flentje, H., Althausen, D., Ansmann, A., and Frey, S.: Ceilometer-lidar inter-comparison: backscatter coefficient retrieval and signal-to-noise ratio determination, Atmos. Meas. Tech. Discuss., 3, 3907-3924, doi:10.5194/amtd-3-3907-2010, 2010.

Institute of Earth Sciences: Eruption in Eyjafjallajökull 20 March to present, available at: http://www.earthice.hi.is/page/ies_EYJO_ compiled, 2010 .

Klett, J.: Stable analytical inversion solution for processing lidar returns, Appl. Optics, 20, 211-220, 1981.

Mannschreck, K., Gilge, S., Plass-Duelmer, C., Fricke, W., and Berresheim, H.: Assessment of the applicability of $\mathrm{NO}-\mathrm{NO}_{2}-$ $\mathrm{O}_{3}$ photostationary state to long-term measurements at the Hohenpeissenberg GAW Station, Germany, Atmos. Chem. Phys., 4, 1265-1277, doi:10.5194/acp-4-1265-2004, 2004.

Miller, T. and Casadevall, T.: Encyclopedia of Volcanoes, chap. Volcanic ash hazards to aviation, 915-930, Elsevier, H. Sigurdsson, New York, 2000.

Prata, A.: Satellite detection of hazardous volcanic ash clouds and the risk to global air traffic, Nat. Hazards, doi:10.1007/ s11096-008-9273-z, 51, 303-324, 2008.

Rose, W. and Durant, A.: Fine ash content of explosive eruptions, J. Volcanol. Geoth. Res., 186, 32-39, doi:10.1016/j.jvolgeores 2009.01.010, 2009.

Schenkel, A. and Broder, B.: Interference of some trace gases with ozone measurements by the KI-method., Atmos. Environ., 16, 2187-2190, 1982.

Schumann, U., Weinzierl, B., Reitebuch, O., Schlager, H., Minikin, A., Forster, C., Baumann, R., Sailer, T., Graf, K., Mannstein, H., Voigt, C., Rahm, S., Simmet, R., Scheibe, M., Lichtenstern, M., Stock, P., Rüba, H., Schäuble, D., Tafferner, A., Rautenhaus, M., Gerz, T., Ziereis, H., Krautstrunk, M., Mallaun, C., Gayet, J.F., Lieke, K., Kandler, K., Ebert, M., Weinbruch, S., Stohl, A., Gasteiger, J., Olafsson, H., and Sturm, K.: Airborne observations of the Eyjafjalla volcano ash cloud over Europe during air space closure in April and May 2010, Atmos. Chem. Phys. Discuss., 10, 22131-22218, doi:10.5194/acpd-10-22131-2010, 2010.

Zerefos, C., Nastos, P., Balis, D., Papayannis, A., Kelepertsis, A., Kanelopoulou, E., Nikolakis, D., Eleftheratos, C., Thomas, W., and Varotsos, C.: A Complex Study of Etna's Volcanic Plume from Ground-based, In-situ and Space-borne Observations, Int. J. Remote Sens., 27, 1855-1864, doi:10.1080/ $01431160500462154,2006$. 